\title{
PLASMINOGEN MODULATES FORMATION OF REACTIVE OXYGEN SPECIES IN HUMAN PLATELETS
}

\author{
A. A. TYKHOMYROV, D. D. ZHERNOSEKOV, M. M. GUZYK, \\ V. V. KORSA, T. V. GRINENKO
}

Palladin Institute of Biochemistry, National Academy of Sciences of Ukraine, Kyiv; e-mail: artem_tykhomyrov@ukr.net

Reactive oxygen species (ROS) are considered to be important signalling molecules controlling many platelet functions. ROS production has been shown to be augmented by platelet activation, however, plasminogen $(\mathrm{Pg})$ has not been studied in the context of modulating intraplatelet ROS levels. The aim of this study was to investigate the ability of different Pg forms to affect platelet metabolic activity/survival and intracellular ROS production in resting and activated platelets. Platelets isolated from donor plasma were pre-treated with Glu- or Lys-Pg $(1.2 \mu \mathrm{M})$ and activated by thrombin (1.0 NIH unit/ml) or collagen $(1.25 \mathrm{mg} /$ $\mathrm{ml})$. MTT assay was adapted to estimate total mitochondrial dehydrogenase activity, while intracellular ROS levels were monitored with the use of $\mathrm{H}_{2} D C F-D A$ probe by flow cytometry. Lys-Pg was shown to slightly, but significantly, mitigate MTT reduction $(P<0.05$ vs. control platelets). Two-fold elevation in metabolic activity of platelets stimulated by thrombin as compared to untreated cells was observed. However, this activation was less exhibited in the case of platelets pre-incubated with either Glu- of Lys-Pg, with a predominant effect of Lys-Pg. Unlike thrombin, collagen treatment dramatically suppressed metabolic activity of platelets by $60 \%$ compared to control $(P<0.05)$. Glu- or Lys-Pg pre-incubation had no effects on the activity of collagenstimulated platelets. Two subpopulations of platelets were observed with distinct characteristics of intracellular ROS formation. Elevated ROS production was demonstrated in these populations of both thrombin-and collagen-treated platelets. Pg (Lys-form to greater extent) enhanced intracellular ROS generation in thrombin-stimulated platelets. These findings suggest that augmented ROS generation within platelets pre-treated with Pg followed by their stimulation may result in down-regulation of their survival and functional activity. This study adds to our understanding one more possible mechanism of Pg impact on the platelet function.

Ke y w o r d s: plasminogen, platelets, reactive oxygen species (ROS), $\mathrm{H}_{2} D C F-D A$, flow cytometry, MTT test.

$\mathrm{P}$ latelets are multifunctional enucleated cell fragments, playing crucial roles in blood clotting, immune response, inflammation, cell proliferation and apoptosis, tissue remodelling and wound healing [1]. The central event in platelet physiology is their activation that includes a complex interplay of adhesion and signaling molecules. It is generally accepted that platelet activation is induced by collagen or soluble platelet agonists that bind Gprotein-coupled receptors, resulting in the activation of platelet adhesion receptors, mainly the integrin $\alpha_{\mathrm{II}} \beta_{3}$, which mediates platelet secretion, adhesion, and aggregation, which are energy-consuming processes [2]. These cells have a greater rate of ATP turnover than resting mammalian muscle cells, sug- gesting they are fairly metabolically active. Resting platelets have been shown to derive approximately $60 \%$ of their ATP from glycolysis, whereas aerobic respiration accounts for $30-40 \%$ of energy basally. However, during platelet activation and secretion, the rate of both glycolysis and aerobic respiration increase significantly to accommodate escalated energy demand [3].

During platelet activation induced by various agonists or upon ligation of platelet receptors through subendothelial matrix proteins, intracellular reactive oxygen species (ROS) are generated, further amplifying platelet activation response. Recent studies have suggested that several ROS, such as superoxide $\mathrm{O}_{2}^{--}$, hydroxyl $\mathrm{HO}$, hydrogen peroxi-

(C) 2018 Tykhomyrov A. A. et al. This is an open-access article distributed under the terms of the Creative Commons Attribution License, which permits unrestricted use, distribution, and reproduction in any medium, provided the original author and source are credited. 
de $\mathrm{H}_{2} \mathrm{O}_{2}$ and others, play a role as secondary messengers in platelet signal transduction, activation, degranulation, adhesion, and aggregation [4, 5]. Several sources of ROS in activated platelets have been identified. One of the main source of ROS is NADPH oxidase (NOX) isoforms, which are activated through the platelet collagen receptor, GPVI, and protease-activated receptors (PAR-1 and -4) evoked by thrombin. Other sources of intraplatelet ROS are cyclooxygenase and 12-lipoxygenase (arachidonic acid metabolism), glutathione cycle, and xanthine oxidase. Accumulating evidence suggests that mitochondria regulate platelet activation beyond simply providing ATP. Platelets activated by thrombin are characterized with mitochondrial oxidative burst and electron leakage from the respiratory chain, while the formation of platelet aggregates is associated with the burst of $\mathrm{H}_{2} \mathrm{O}_{2}$ [6]. The formation of ROS occurs when unpaired electrons escape the electron transport chain and react with molecular oxygen, generating ROS. Production of mitochondrial ROS is closely linked with changes in mitochondrial membrane potential, while increase in membrane potential (hyperpolarization) can augment the reduction of the electron transport chain resulting in the leak of electrons out of the chain and subsequent $\mathrm{O}_{2}{ }^{--}$ generation. Complexes I, II, and III of the electron transport chain are the major potential loci for ROS generation [7].

It has been shown that ROS are involved in regulation of conformational state of the key protein receptors responsible for ligand-receptor interactions during platelet aggregation. ROS induce changes in intraplatelet $\mathrm{Ca}^{2+}$ homeostasis, thus maybe serve as secondary messengers in thrombin- or collagen-activated platelets. However, other potential mechanism of how ROS regulate signaling pathways is through oxidation of cysteine residues of signaling proteins. Several studies indicate ROS to regulate the activation of integrin $\alpha \operatorname{IIb} \beta 3$ and the subsequent aggregation of platelets and thrombus growth [8,9]. On the other hand, ROS imbalance could potentially impact platelet function in either reversible or irreversible ways. An increase in intracellular ROS beyond a certain threshold level will harm activity of platelets and down-regulate their adhesive function [10]. Earlier data indicate that mitochondrial ROS is involved in the apoptotic process [11]. Understanding these metabolic changes is important in designing new approaches to modulate platelet function, and assessing the impact of current interventions for cardiovascu- lar diseases, cancer or other pathologies associated with abnormal platelet bioenergetic capacity.

Pg is a circulating non-active zymogen of plasmin (Pm) (EC 3.4.21.7), which is best known for its function as a key enzyme of the fibrinolytic cascade [12]. There are two forms of Pg, the native predominant Glu-Pg and the intermediate form Lys-Pg, which is formed by partial cleavage of Glu-Pg on the fibrin matrix or cell surface. It is important to note that Lys-Pg represents an open conformation that is more readily converted into Pm than Glu-form [13]. $\mathrm{Pg} / \mathrm{Pm}$ can bind to various cells to regulate their functional activity [14]. Our recent findings add to a growing literature that $\mathrm{Pg} / \mathrm{Pm}$ system has a number of crucial functions beyond fibrinolysis. We have earlier shown that Lys-Pg, but not native proenzyme, is able to inhibit agonist-induced platelet aggregation [15]. In order to verify possible mechanisms of such effects, it has been demonstrated that Lys-Pg interferes agonist-stimulated reconstruction of actin cytoskeleton [16] and suppresses $\alpha$-granule release [17]. However, how Glu- or Lys-isoforms of Pg might alter the key intraplatelet signaling events remains still unknown. Hence, the aim of the present study was to investigate the ability of different Pg forms to affect metabolic activity (as a measure of cell survival) and intracellular ROS production in resting and activated platelets.

\section{Materials and Methods}

Reagents and proteins. 3-(4,5-dimethylthiazol-2-yl)-2,5-diphenyltetrazolium bromide (tetrazolium dye MTT), $\mathrm{H}_{2}$ DCF-DA, bovine serum albumin (BSA), $\alpha$-thrombin (EC 3.4.21.5), glucose, 4-(2-hydroxyethyl)-1-piperazineethanesulfonic acid (HEPES), dimethyl sulfoxide (DMSO), and other chemicals and reagents were from Sigma Aldrich (USA) except for those specified.

Glu-Pg from fresh human plasma was purified by affine chromatography on Lys-sepharose 4B (GE Healthcare Life Sciences, USA) as described elsewhere [18]. Human Lys-Pg was isolated from the frozen human plasma Cohn fraction III paste [19, 20]. Both forms of Pg were of electrophoretic purity and did not exhibit spontaneous proteolytic activity.

Platelet preparation and experimental design. Blood from five normal drug-free healthy male volunteers was collected by phlebotomy without vacuum into 3.2\% sodium citrate as anticoagulant in polypropylene tubes. Blood was centrifuged at $160 \mathrm{~g}$ for $20 \mathrm{~min}$ at room temperature for platelet rich 
plasma (PRP) isolation. Then, washed platelets were obtained from PRP by gel-filtration on the $10 \mathrm{ml} \mathrm{Se}-$ pharose CL-2B column (GE Healthcare Bio-Sciences AB, Uppsala, Sweden). HEPES buffer $(20 \mathrm{mM}$ HEPES, pH 6.8, $137 \mathrm{mM} \mathrm{NaCl}, 4 \mathrm{mM} \mathrm{KCl}, 0.2 \mathrm{mM}$ $\mathrm{MgCl}_{2}, 0.2 \%$ glucose and $0.2 \% \mathrm{BSA}$ ) was used for the elution of platelets in the void volume. All assays were performed within 60-80 min after platelet collection. To check functional response on agonist's action, platelet aggregation was monitored in a Solar AT-02 light transmitting aggregometer (Republic of Belarus) using washed platelets adjusted to $10^{7}$ cells/ $\mathrm{ml}$ under constant stirring at $37^{\circ} \mathrm{C}$.

To estimate effects of Pg isoforms on the studied parameters, platelets were preincubated with Glu- or Lys-Pg (1.2 $\mu \mathrm{M}$ final concentration) for $3 \mathrm{~min}$ at $37^{\circ} \mathrm{C}$. For platelet activation, thrombin $(1.0 \mathrm{NIH}$ units $/ \mathrm{ml}$ ) or collagen (Tehnologiia Standart, Russian Federation) $(1.25 \mathrm{mg} / \mathrm{ml})$ were added to untreated or Pg-pretreated platelets for $5 \mathrm{~min}$. After treatment, platelets were immediately washed from studied proteins by two-time centrifugation (1,000 g for $10 \mathrm{~min}$ at $25^{\circ} \mathrm{C}$ ) in phosphate buffered saline (PBS). Nontreated platelets were processed in the same manner except physiological saline was added as vehicle (resting control).

MTT-assay. The MTT assay is based on the intracellular conversion of a tetrazolium, which is reduced to purple formazan by $\mathrm{NAD}(\mathrm{P}) \mathrm{H}$-dependent mitochondrial dehydrogenases indicating normal cell metabolism [21]. Intact and treated platelets were sedimented and the pellets were resuspended in MTT solution (1 mg/ml PBS). Platelets resuspended in pure PBS were used as a negative control. Platelets were allowed to reduce MTT for $60 \mathrm{~min}$ at $37^{\circ} \mathrm{C}$ with MTT, and then were washed from the MTT residues by the centrifugation at $16,000 \mathrm{~g}$ for $20 \mathrm{~min}$ at $4{ }^{\circ} \mathrm{C}$. Supernatants were discarded, and then intracellular water-insoluble formazan crystals were dissolved in $1 \mathrm{ml}$ DMSO. Resultant absorbance values were measured with the use of SF-2000 spectrophotometer (Russia Federation) at $\lambda=500$ and $630 \mathrm{~nm}$. Each tested sample was measured in triplicate. The results were expressed as $\Delta(500-630 \mathrm{~nm})$.

Flow cytometry (intraplatelet ROS measurements). $\mathrm{H}_{2} \mathrm{DCF}-\mathrm{DA}$ is currently used in flow cytometry analyses for direct and reliable relative quantification of intracellular ROS. After cytosolic hydrolysis, $\mathrm{H}_{2}$ DCF-DA can be oxidized into $2^{\prime}, 7^{\prime}$-dichlorofluorescein (DCF), which fluoresces at $520 \mathrm{~nm}$. One of the main advantages of this tech- nique is that it allows the rapid detection of ROS, so that even short-lived oxidative imbalance can be measured [22].

Platelets were incubated with the studied proteins as described above, washed and loaded with $12.5 \mu \mathrm{M} \mathrm{H}_{2}$ DCF-DA in PBS. After $30 \mathrm{~min}$ incubation at $37^{\circ} \mathrm{C}$ in the dark chamber, samples were diluted with 5-fold ice-cold PBS and kept on ice until analyzed. All flow cytometry analysis was performed on a Coulter Epics XL device (Beckman Coulter, USA) via FL2 channel (575 nm). Population of untreated (control) platelets was chosen for threshold value setting. DCF-positive platelet population was gated separately on the basis of side-scattered light (SSC). For all samples, at least 15,000 events were analyzed. The measurement of cytometric parameters in each group of platelets was done in duplicate, and the mean value was calculated based on the values obtained from all donors. For all ROS experiments, median DCF fluorescence intensity values were recorded and expressed as arbitrary units. The results were analyzed and presented using "FCS Express V3" software system (De Novo Software, USA).

Statistical analysis. All results are given as mean and standard error of mean $(M \pm m)$. A $t$-test or Mann-Whitney's U-test were used to calculate $P$ value. A $P$ value less than $0.05(P<0.05)$ was considered significant.

\section{Results and Discussion}

MTT-test, which is conventionally utilized for evaluation of viability or proliferative capability of nucleated cells, was adopted for assessment of changes in metabolic activity of platelets treated with the studied proteins. The results of these measurements are depicted in Fig. 1.

It was demonstrated that washed human platelets were able to reduce a tetrazolium salt by their mitochondrial dehydrogenases. Although the effect of Glu-Pg $(1.2 \mu \mathrm{M})$ on platelet metabolic activity was minimal, the same concentration of Lys-Pg mitigated MTT reduction slightly, but in a statistically significant way. Two-fold elevation in formazan level in platelets activated by thrombin (1.0 NIH units/ml) as compared to untreated cells was observed after 60 min incubation with tetrazolium salt. However, this activation was less exhibited in the case of platelets preincubated with either Glu- of Lys-Pg, with a predominant effect of Lys-Pg. Unlike thrombin, collagen treatment suppressed metabolic activity 


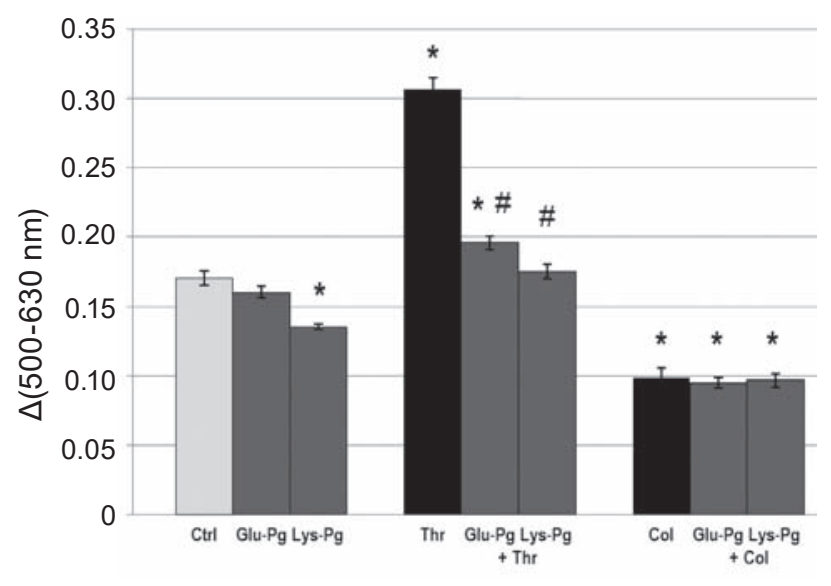

Fig. 1. Effects of Glu- or Lys-plasminogen on metabolic activity of resting and activated platelets (by MTT-test results): Ctrl - control, Thr - thrombin, Col-collagen; $* P<0.05$ vs. Ctrl, \# $P<0.05$ vs. Thr

of platelets by $60 \%$ compared to control $(P<0.05)$. It is important to note that Glu- or Lys-Pg preincubation had no effects on the activity of collagenstimulated platelets. These data indicate that Pg can affect NAD(P)H-dependent metabolic pathways of platelets, however, its effects significantly depends on the agonist used for platelet activation. Collagen is considered to be one of the most potent platelet activator and ROS formation inductor [23]. Possibly, reducing platelet metabolic activity observed in our experiment after collagen stimulation can be a result of oxidative burst induced by submaximal concentration of agonist.

Next, in order to verify if Pg can affect agonist-induced redox signalling mechanisms, we used a redox-sensitive fluorescent dye $\left(\mathrm{H}_{2}\right.$ DCF-DA) to quantify intraplatelet ROS levels by flow cytometric assay. The platelets were selected on the basis of side scattering (SSC) and DCF-fluorescence (FL2). As shown in Fig. 2, the vast majority of washed resting platelets (Ctrl) (> 98\%) were counted as DCF-positive events, indicating high percentage of viable and functionally active cells studied in ex vivo conditions. This also means that during platelet isolation and resuspension a partial activation of these cells may occur. Our data corroborate with the earlier report describing ability of platelets isolated by centrifugation to produce $\mathrm{O}_{2}{ }^{--}$[5]. Cell sorting allowed detecting two discrete subpopulations of living platelets, which differ ultrastructurally and were distinct by the ability to produce ROS.
The smaller subset (gate I, red) represents preactivated platelets, which have been earlier identified to expose increased P-selectin levels even in the samples of non-stimulated cells [15]. The number of such cells did not exceed $\sim 9 \%$ of all the platelets analyzed (Fig. 2 and 3). The larger subset (gate II, blue) corresponds to the main platelet population ( 90\%), characterized by lower ROS production capability than the first platelet subset.

Flow cytometry gave the possibility to analyze Pg and agonist-induced redistribution of platelets and to make a quantification of such changes. In response to treatment with Glu- or Lys-Pg, ROS production by the first population was slightly, but significantly $(P<0.05)$, increased (Fig. 3). However, the number of platelets inside the gates remained unchanged (Fig. 4). Elevated ROS production was demonstrated in both populations of thrombin-treated platelets. The most intriguing observation was that Pg elicited ROS generation in thrombin-stimulated platelets (Lys-form to greater extent). Moreover, thrombin increased the number of platelets in gate I up to $24 \%$.

In the case of collagen stimulation, dramatic redistribution of platelets into gate I and elevating DCF-positive signal were observed. Average number of highly activated platelets reached $29 \%$ after incubation with collagen. Surprisingly, pre-treatment of platelets with Pg resulted in increasing count of platelets in gate I followed by collagen activation (40 and 36\% for Glu-Pg and Lys-Pg groups, respectively).

Our previous investigations have demonstrated that Lys-Pg is able to affect the key platelet responses, including cytoskeletal rearrangement, secretion, and aggregation [15-17], while Glu-Pg can be considered as a co-stimulator of agonist-induced platelet secretion and procoagulant surface formation [24]. Nevertheless, the intimate molecular mechanisms of such effects remain poorly understood. It can be assumed that Pg-induced alterations can be due to $\mathrm{Pm}$ formation on the platelet surface. Pm is capable of triggering signaling in various cell types, which depends on cellular binding via its lysinebinding sites and its proteolytic activity [25]. In vitro and in vivo studies have demonstrated the ability of Pm to stimulate the production of cytokines, ROS, intracellular increase in $\mathrm{Ca}^{2+}$ and other mediators, thereby even contributing to cell death [26]. Recent$1 y$, it has been demonstrated that direct effects of Pm on platelets, including the intracellular $\mathrm{Ca}^{2+}$ increase 

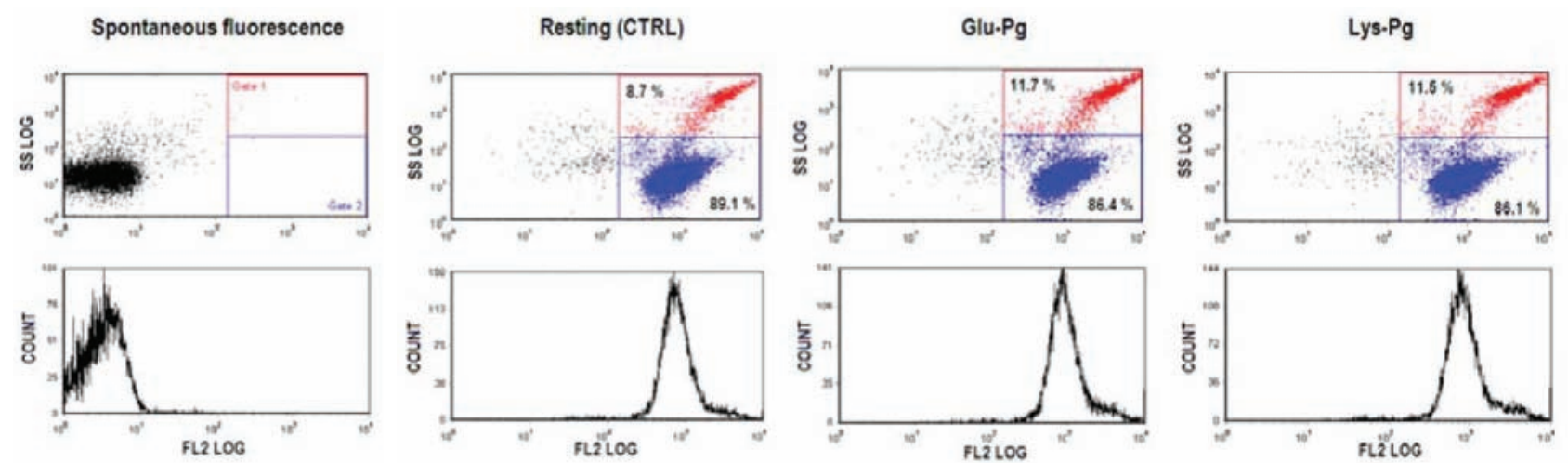

Thrombin
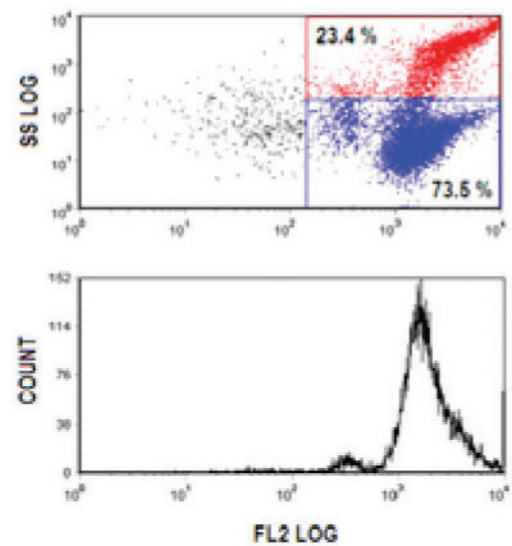

Collagen
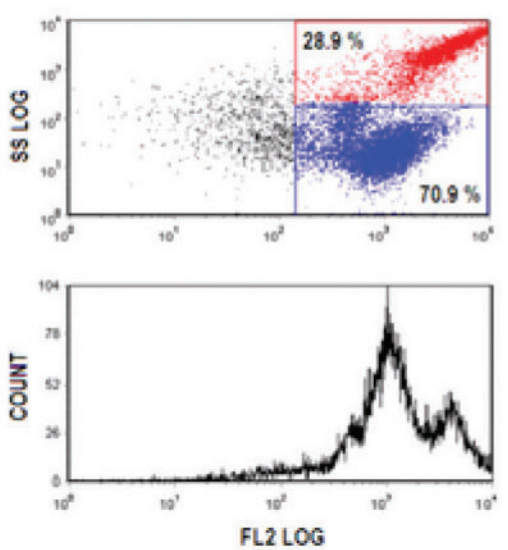

Glu-Pg + thrombin
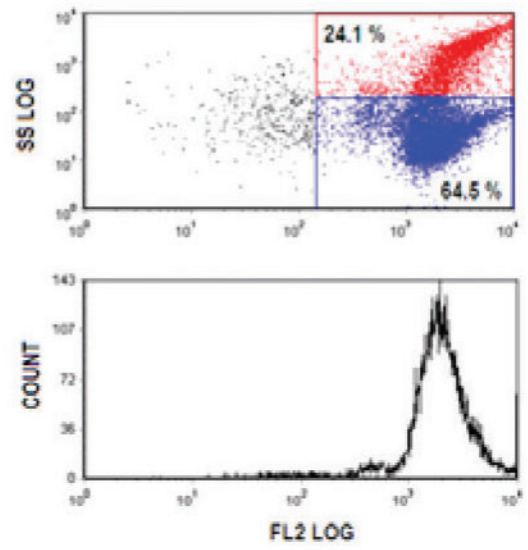

Glu-Pg + collagen
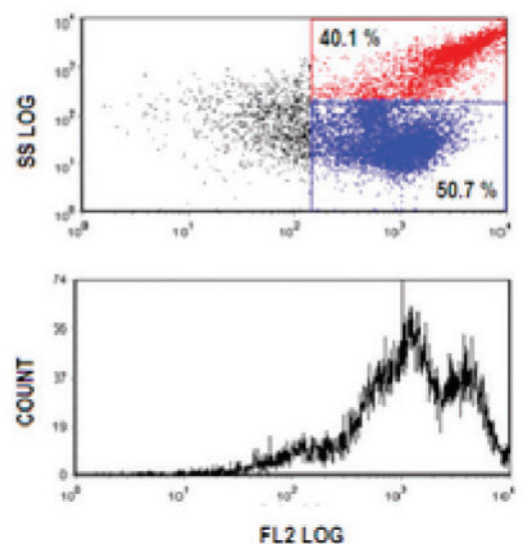

Lys $\cdot \mathrm{Pg}+$ thrombin
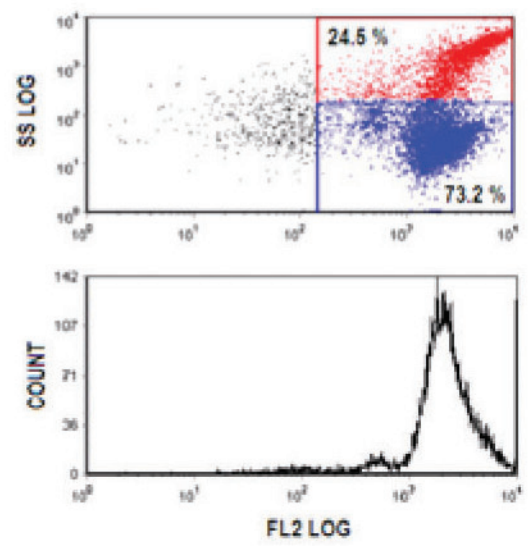

Lys $\cdot \mathrm{Pg}+$ collagen
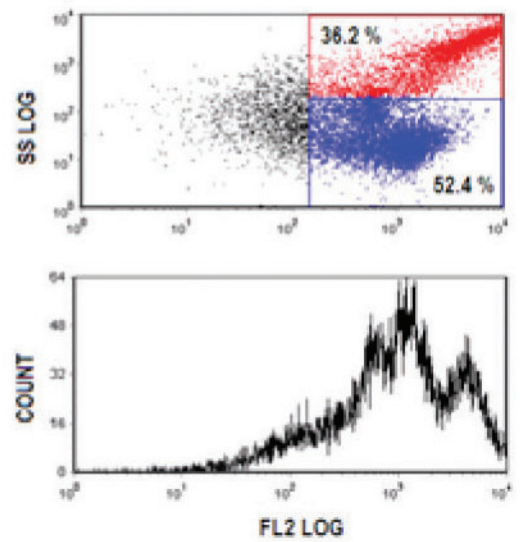

Fig. 2. Effects of Glu- or Lys-plasminogen on intraplatelet ROS generation: representative flow cytometric dot plots and histograms of platelet subpopulations

and platelet aggregation, are mediated mainly by the low-affinity thrombin receptor PAR4 [27]. On the other hand, truncation of PAR-1 at the C-terminal $\mathrm{Pm}$-cleavage sites removes the $\mathrm{N}$-terminal tethered ligand or preligand, thereby providing an effective pathway for PAR1 desensitization [28]. It has been suggested that PAR4 plays a major role in calcium signaling and the induction of sustained aggregation, while PAR1 shows a more prominent role in platelet secretion and synthesis. Coughlin [29] has described 

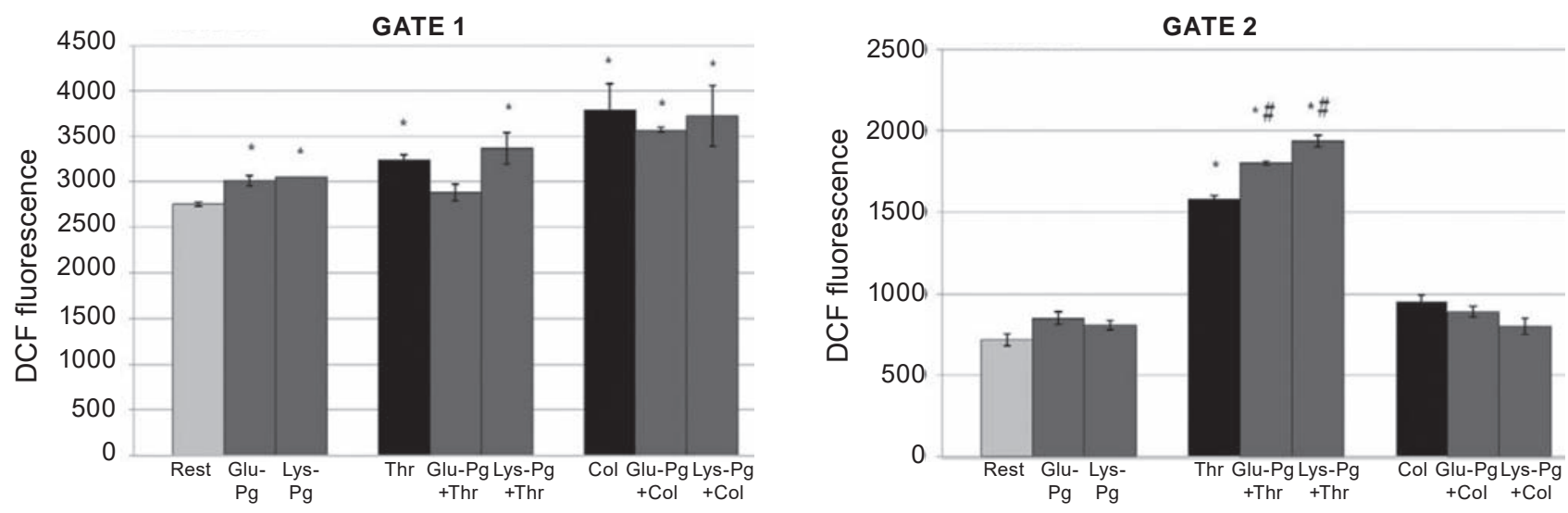

Fig. 3. Effects of Glu- or Lys-plasminogen on intracellular ROS generation by resting and activated platelets expressed as DCF fluorescence intensities. Rest-resting (control) platelets, Thr - thrombin, Col - collagen; $* P<0.05$ vs. Rest, \#P<0.05 vs. Thr

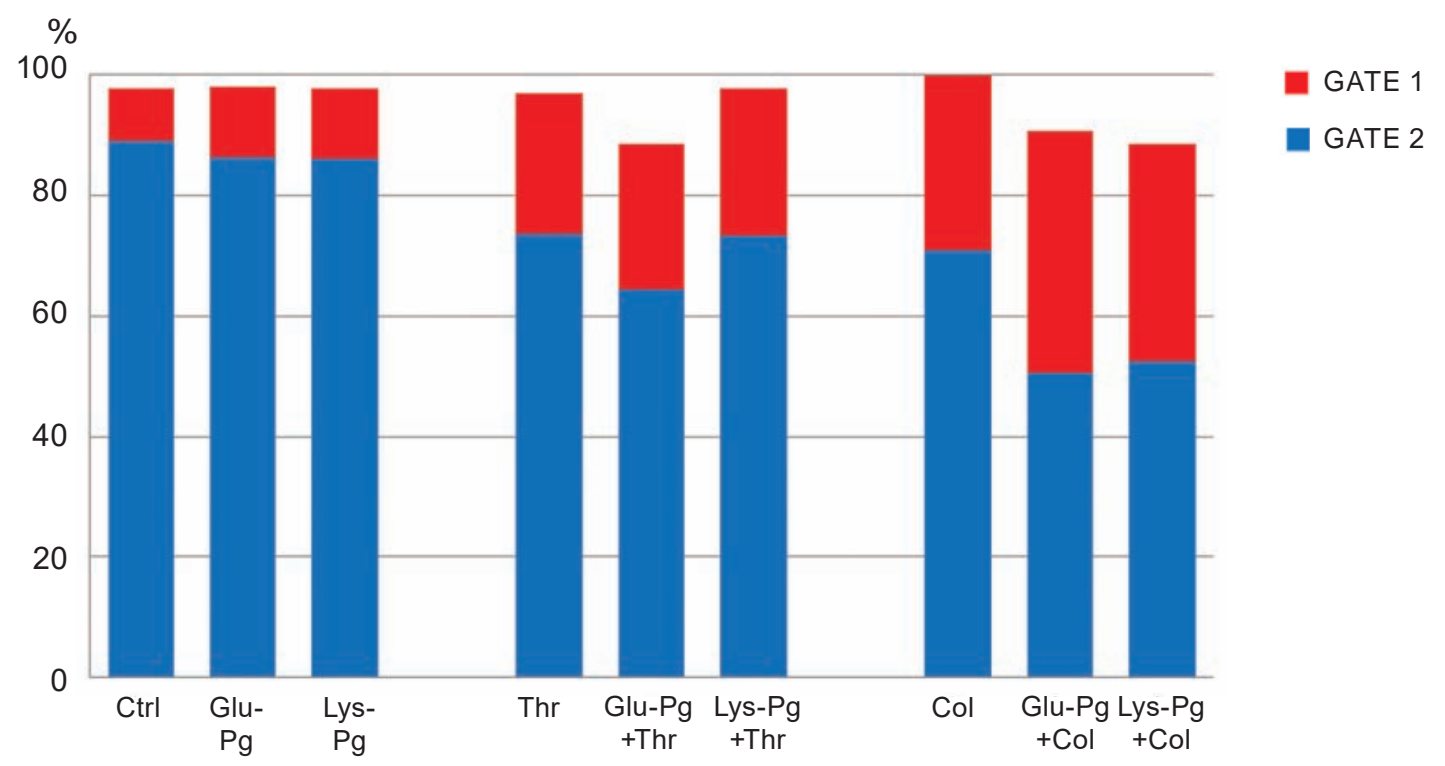

Fig. 4. Redistribution of platelet subsets induced by Glu- or Lys-plasminogen. Rest - resting (control) platelets, Thr - thrombin, Col - collagen

that PAR-1 is a primary receptor mediating platelet apoptosis. Other studies have provided evidence that Pm/PAR1 axis is implicated in triggering apoptosis and excitotoxicity in neurons, astrocytes, and microglia; Pm inhibitors have been found to be neuroprotective [30]. In the bloodstream, Pg circulates predominantly as a native protein (Glu-Pg). However, on the platelet surface Glu-Pg can be easily turned to a partially truncated form, or Lys-Pg. It should be kept in mind that the latter has an open conformation and is more readily converted into Pm by Pg activators $[12,13]$. This fact could explain why Lys-Pg exhibits more pronounced effect to stimulate ROS generation than Glu-form, even if incubated alone with resting platelets.

Data obtained by cytometry assay indicate that modulating effects of $\mathrm{Pg}$ depends on the nature of agonist used for platelet activation. Changes in platelet sub-population profiles induced by Pg may reflect distinct signaling downstream events affected during Pg treatment. There are a few agonist-induced activation pathways that produce ROS, including the collagen, thrombin, and arachidonic acid activation pathways. As expected, thrombin stimulation greatly enhances platelet redox signaling (Fig. 3). It is important to note that ROS levels within thrombin- 
stimulated platelets pretreated with Pg appeared to be higher than that for platelets treated with thrombin only. Thrombin is a potent platelet activator and a GPIb $\alpha$ and PAR's agonist [31]. Treatment of platelets with thrombin stimulates mitochondrial membrane potential depolarization and endogenous generation of hydrogen peroxide [4]. Upon activation, platelets undergo rapid changes in cell surface receptor expression that lead to altered adhesive properties and exposing additional binding sites for Pg molecules. Pm, which is converted from Pg on the platelet surface, can partially cleave and stimulate both thrombin-activated PAR-1 and -4 [27]. It can be hypothesized that $\mathrm{Pm}$ and thrombin act synergistically to stimulate intraplatelet production of reactive oxygen entities. The findings of Ghasemzadeh [10] indicate that augmented ROS generation during storage might be relevant to down-regulation of platelet adhesive function. Therefore, overproduction of ROS in platelets co-exposed to Pg and thrombin may result in cell activity suppression due to the oxidative stress that is confirmed by the data of MTT assay (Fig. 1).

Platelet adherence to collagen is recognized as a critical initial event for generation of haemostatic plug [32]. Collagen has been found to be the most potent ROS-generating agonist and inductor of apoptosis-like events in platelets [23]. It has been also shown that collagen-mediated GPVI-dependent intracellular oxidative burst in human platelets is maximally initiated within 2 min after stimulation [33]. Previous studies with Nox inhibitors have indicated that $\mathrm{NAD}(\mathrm{P}) \mathrm{H}$ oxidase is responsible for the ROS production in GPVI-stimulated platelets [5, 8]. Flow cytometry assay indicates that collagen, in contrast to thrombin, dramatically abolished reduction of tetrazolium by platelet mitochondrial dehydrogenases. It is possible that $\mathrm{Pg} / \mathrm{Pm}$ and collagen synergistically activate platelets by PARs and GPVI, respectively, inducing oxidative damage to such hyper-stimulated cells. This observation can explain rapid loss of platelet activity in MTT-test during 60 min period (Fig. 1). It is worth noting that several physiological stimuli that cause platelet activation at low concentrations propagate platelet apoptosis at higher concentrations. This is consistent with studies demonstrating that platelet activators increase mitochondrial membrane potential at low concentrations, whereas prolonged exposure to higher concentrations induces the collapse of membrane potential [7]. In addition, the recent research of Whyte et al.
[34] indicates that functional Pg pool accumulates on the platelet membrane following strong agonist stimulation under physiological flow conditions. Pg has been shown to bind directly to platelets, but predominantly with phosphatidylserine (PS)-exposing platelets with shortened survival, which are underwent apoptosis [35]. Moreover, this sub-population of platelets displays an enhanced capacity to generate Pm on their surface, which is thought to be involved in modulating local fibrinolysis.

Conclusion. ROS have been demonstrated as critical signals regulating platelet activity, while their generation correlates with P-selectin expression and platelet aggregation, which are energy-consuming processes. However, overproduction of ROS can harm platelet adhesive activity or cause apoptosis. In the present paper, we demonstrated for the first time that $\mathrm{Pg}$ is able to enhance ROS production in activated platelets and to reduce their viability. Considering that the surface of platelets expose more binding sites for Pg when they are activated in the site of vessel injury, suppression of platelet activity by Pg (especially by Lys-form) may impact on the function of these cells in coagulation. Such dual targeting/signaling can be potentially important in vivo, when significantly high concentrations of thrombin present close to a thrombus, and Pg may act restricting further thrombogenesis when additional platelets may not be needed.

Acknowledgments. The authors are grateful to Dr. Roka-Moya Y.M. for her technical assistance.

\section{ПЛАЗМІНОГЕН МОДУЛЮЄ УТВОРЕННЯ АКТИВНИХ ФОРМ ОКСИГЕНУ ТРОМБОЦИТАМИ ЛЮДИНИ}

\author{
А. О. Тихомиров, Д. Д. Жерносєков, \\ М. М. Гузик, В. В. Корса, Т. В. Гриненко \\ Інститут біохімії ім. О. В. Палладіна \\ НАН України, Київ; \\ e-mail: artem_tykhomyrov@ukr.net
}

Активні форми оксигену (АФО) є важливими сигнальними молекулами, які контролюють функціонування тромбоцитів, а їх продукція підсилюється під час тромбоцитарної активації. Модуляторні ефекти плазміногену (Pg) на утворення АФО тромбоцитами раніше не досліджувалися. Метою цієї роботи було визначити здатність різних форм Pg впливати на метабо- 
лічну активність/виживаність тромбоцитів та утворення ними АФО в стані спокою і за умов активації. Тромбоцити, ізольовані із плазми донорів, преінкубували з Glu- або Lys-Pg $(1,2 \mu \mathrm{M})$ та активували тромбіном (1,0 од. NIH/мл) або колагеном (1,25 мг/мл). Загальну дегідрогеназну активність мітохондрій визначали за допомогою МТТ-тесту, протокову цитофлуориметрію 3 використанням зонду $\mathrm{H}_{2}$ DCF-DA застосовували для вимірювання внутрішньоклітинних рівнів АФО. Встановлено, що Lys-Pg незначним чином пригнічує відновлення МТТ ( $P<0,05$ проти контролю). Тромбін спричинював дворазове збільшення рівня метаболічної активності тромбоцитів порівняно з інтактними клітинами. Однак активація, індукована тромбіном, була менш вираженою у разі тромбоцитів, преінкубованих 3 Pg, причому Lys-Pg спричинював більший інгібувальний ефект. На відміну від тромбіну колаген значно пригнічував метаболічну активність тромбоцитів (на $60 \%$ від контрольної величини, $P<0,05)$. Glu- та Lys-Pg не впливали на активність колагенстимульованих тромбоцитів у МТT-тесті. Сортінг тромбоцитів за здатністю продукувати АФО виявив дві різні субпопуляції клітин. Зростання продукції АФО спостерігалося за активації тромбоцитів як тромбіном, так i колагеном. Pg (Lys-форма більшою мірою) підсилював внутрішньоклітинну генерацію АФО у тромбінстимульованих тромбоцитах. Показано, що посилення Pg генерації АФО, яке передує дії агоністів, може призводити до зниження їх життєздатності та функціональної активності. Це дослідження доповнює уявлення про можливі механізми впливу Pg на функціонування тромбоцитів.

К л ю ч о в і с л о в а: плазміноген, тромбоцити, активні форми оксигену (АФО), $\mathrm{H}_{2} \mathrm{DCF}-$ $\mathrm{DA}$, протокова цитофлуориметрія, МТТ-тест.

\section{ПЛАЗМИНОГЕН МОДУЛИРУЕТ ОБРАЗОВАНИЕ АКТИВНЫХ ФОРМ КИСЛОРОДА ТРОМБОЦИТАМИ ЧЕЛОВЕКА}

А. А. Тихомиров, Д. Д. Жерносеков, М. М. Гузик, В. В. Корса, Т. В. Гриненко
Институт биохимии им. А. В. Палладина НАН Украины, Киев; e-mail: artem_tykhomyrov@ukr.net

Активные формы кислорода (АФК) являются важными сигнальными молекулами, которые контролируют функционирование тромбоцитов, а их продукция усиливается в ходе тромбоцитарной активации. Модуляторные эффекты плазминогена ( $\mathrm{Pg}$ ) на образование АФК тромбоцитами ранее не изучались. Целью представленной работы было определить влияние различных форм Pg на метаболическую активность/ выживание тромбоцитов и образование ими АФК в состоянии покоя и в условиях активации. Тромбоциты, изолированые из плазмы доноров, преинкубировали с Glu- или Lys-Pg $(1,2 \mu \mathrm{M})$ и активировали тромбином (1,0 ед. NIH/мл) или коллагеном (1,25 мг/мл). Общую дегидрогеназную активность митохондрий оценивали с помощью МТТ-теста, проточную цитофлуориметрию с использованием зонда $\mathrm{H}_{2}$ DCF-DA применяли для измерения внутриклеточных уровней АФК. Установлено, что Lys-Pg незначительным образом угнетает восстановление МТT $(P<0,05$ относительно контроля). Тромбин вызывал двукратное усиление уровня метаболической активности тромбоцитов по сравнению с интактными клетками. Однако активация, индуцированная тромбином, была менее выраженной в случае тромбоцитов, преинкубированных с Рg, причем Lys-Pg обладал более сильным ингибирующим эффектом. В отличие от тромбина коллаген су- 
щественно угнетал метаболическую активность тромбоцитов (на $60 \%$ от контрольной величины, $P<0,05)$. Glu- и Lys-Pg не влияли на активность в МТТ-тесте коллагенстимулированных тромбоцитов. Сортинг тромбоцитов по способности продуцировать АФК выявил две различные популяции клеток. Усиление продукции АФК наблюдалось при активации тромбоцитов как тромбином, так и коллагеном. Pg (Lys-форма в большей степени) интенсифицировал внутриклеточную генерацию АФК в тромбинстимулированных тромбоцитах. Показано, что усиление Pg продукции АФК, предшествующее действию агонистов, может приводить к снижению жизнеспособности и функциональной активности клеток. Данное исследование дополняет представления о возможных механизмах влияния $\mathrm{Pg}$ на функционирование тромбоцитов.

К л юч е вы е с лов а: плазминоген, тромбоциты, активные формы кислорода (АФК), $\mathrm{H}_{2} \mathrm{DCF}-\mathrm{DA}$, проточная цитофлуориметрия, MTT-тест.

\section{References}

1. Mancuso ME, Santagostino E. Platelets: much more than bricks in a breached wall. $\mathrm{Br} J$ Haematol. 2017; 178(2): 209-219.

2. Estevez B, Du X. New Concepts and Mechanisms of Platelet Activation Signaling. Physiology (Bethesda). 2017; 32(2): 162-177.

3. Kramer PA, Ravi S, Chacko B, Johnson MS, Darley-Usmar VM. A review of the mitochondrial and glycolytic metabolism in human platelets and leukocytes: implications for their use as bioenergetic biomarkers. Redox Biol. 2014; 2: 206-210.

4. Carrim N, Arthur JF, Hamilton JR, Gardiner EE, Andrews RK, Moran N, Berndt MC, Metharom P. Thrombin-induced reactive oxygen species generation in platelets: A novel role for protease-activated receptor 4 and GPIb $\alpha$. Redox Biol. 2015; 6: 640-647.

5. Wachowicz B, Olas B, Zbikowska HM, Buczyński A. Generation of reactive oxygen species in blood platelets. Platelets. 2002; 13(3): 175-182.

6. Ravi S, Chacko B, Sawada H, Kramer PA, Johnson MS, Benavides GA, O'Donnell V, Marques MB, Darley-Usmar VM. Metabolic plasticity in resting and thrombin activated platelets. PLoS One. 2015; 10(4): e0123597.
7. Zharikov S, Shiva S. Platelet mitochondrial function: from regulation of thrombosis to biomarker of disease. Biochem Soc Trans. 2013; 41(1): 118-123.

8. Krötz F, Sohn HY, Pohl U. Reactive oxygen species: players in the platelet game. Arterioscler Thromb Vasc Biol. 2004; 24(11): 1988-1996.

9. Begonja AJ, Gambaryan S, Geiger J, Aktas B, Pozgajova M, Nieswandt B, Walter U. Platelet NAD(P)H-oxidase-generated ROS production regulates alphaIIbbeta3-integrin activation independent of the NO/cGMP pathway. Blood. 2005; 106(8): 2757-2760.

10. Ghasemzadeh M, Hosseini E, Roudsari ZO, Zadkhak $\mathrm{P}$. Intraplatelet reactive oxygen species (ROS) correlate with the shedding of adhesive receptors, microvesiculation and platelet adhesion to collagen during storage: Does endogenous ROS generation downregulate platelet adhesive function? Thromb Res. 2018; 163: 153-161.

11. Wang Z, Wang J, Xie R, Liu R, Lu Y. Mitochondria-derived reactive oxygen species play an important role in Doxorubicin-induced platelet apoptosis. Int J Mol Sci. 2015; 16(5): 11087-11100.

12. Law RH, Abu-Ssaydeh D, Whisstock JC. New insights into the structure and function of the plasminogen/plasmin system. Curr Opin Struct Biol. 2013; 23(6): 836-841.

13. Fredenburgh JC, Nesheim ME. Lys-plasminogen is a significant intermediate in the activation of Glu-plasminogen during fibrinolysis in vitro. J Biol Chem. 1992; 267(36): 26150-26156.

14. Miles LA, Castellino FJ, Gong Y. Critical role for conversion of glu-plasminogen to Lys-plasminogen for optimal stimulation of plasminogen activation on cell surfaces. Trends Cardiovasc Med. 2003; 13(1): 21-30.

15. Roka-Moya YM, Zhernossekov DD, Yusova EI, Kapustianenko LG, Grinenko TV. Study of the sites of plasminogen molecule which are responsible for inhibitory effect of Lysplasminogen on platelet aggregation. $U k r$ Biochem J. 2014; 86(5): 82-88.

16. Tykhomyrov AA, Zhernosekov DD, RokaMoya YM, Diordieva SI, Grinenko TV. Effects of Lys-form of plasminogen on platelet actin cytoskeleton. Fiziol Zh. 2014; 60(1): 25-33. (In Ukrainian). 
17. Tykhomyrov AA, Zhernosekov DD, Roka-Moya YM, Diordieva SI, Grinenko TV. The effects of Lys-plasminogen on human platelet secretion. Fiziol Zh. 2015; 61(6): 26-34. (In Ukrainian).

18. Grant AJ. Modifications to the lysine Sepharose method of plasminogen purification which ensure plasmin-free Glu-plasminogen. Biochem Int. 1990; 20(3): 519-527.

19. Summaria L, Spitz F, Arzadon L, Boreisha IG, Robbins KC. Isolation and characterization of the affinity chromatography forms of human Glu- and Lys-plasminogens and plasmins. J Biol Chem. 1976; 251(12): 3693-3699.

20. Collen D, Ong EB, Johnson AJ. Human plasminogen: in vitro and in vivo evidence for the biological integrity of NH2-terminal glutamic acid plasminogen. Thromb Res. 1975; 7(4): 515-529.

21. Li J, Lockerbie O, de Korte D, Rice J, McLean R, Goodrich RP. Evaluation of platelet mitochondria integrity after treatment with Mirasol pathogen reduction technology. Transfusion. 2005; 45(6): 920-926.

22. Aranda A, Sequedo L, Tolosa L, Quintas G, Burello E, Castell JV, Gombau L. Dichlorodihydro-fluorescein diacetate (DCFH-DA) assay: a quantitative method for oxidative stress assessment of nanoparticle-treated cells. Toxicol In Vitro. 2013; 27(2): 954-963.

23. Jang JY, Min JH, Chae YH, Baek JY, Wang SB, Park SJ, Oh GT, Lee SH, Ho YS, Chang TS. Reactive oxygen species play a critical role in collagen-induced platelet activation via SHP-2 oxidation. Antioxid Redox Signal. 2014; 20(16): 2528-2540.

24. Zhernossekov D, Roka-Moiia Y, Tykhomyrov A, Guzyk M, Grinenko T. Glu- and Lysforms of plasminogen differentially affect phosphatidylserine exposure on the platelet surface. Ukr Biochem J. 2017; 89(Special Issue): 102-110.

25. Godier A, Hunt BJ. Plasminogen receptors and their role in the pathogenesis of inflammatory, autoimmune and malignant disease. $J$ Thromb Haemost. 2013; 11(1): 26-34.
26. Syrovets T, Lunov O, Simmet T. Plasmin as a proinflammatory cell activator. J Leukoc Biol. 2012; 92(3): 509-519.

27. Quinton TM, Kim S, Derian CK, Jin J, Kunapuli SP. Plasmin-mediated activation of platelets occurs by cleavage of proteaseactivated receptor 4. J Biol Chem. 2004; 279(18): 18434-18439.

28. Kuliopulos A, Covic L, Seeley SK, Sheridan PJ, Helin J, Costello CE. Plasmin desensitization of the PAR1 thrombin receptor: kinetics, sites of truncation, and implications for thrombolytic therapy. Biochemistry. 1999; 38(14): 4572-4585.

29. Coughlin SR. Protease-activated receptors in hemostasis, thrombosis and vascular biology. J Thromb Haemost. 2005; 3(8): 1800-1814.

30. Greenidge AR, Hall KR, Hambleton IR, Thomas R, Monroe DM, Landis RC. Plasmin Activation of Glial Cells through ProteaseActivated Receptor 1. Patholog Res Int. 2013; 2013: 314709.

31. Leytin V, Allen DJ, Mykhaylov S, Lyubimov E, Freedman J. Thrombin-triggered platelet apoptosis. J Thromb Haemost. 2006; 4(12): 2656-2663.

32. Nuyttens BP, Thijs T, Deckmyn H, Broos K. Platelet adhesion to collagen. Thromb Res. 2011; 127(Suppl 2): S26-S29.

33. Qiao J, Arthur JF, Gardiner EE, Andrews RK, Zeng L, Xu K. Regulation of platelet activation and thrombus formation by reactive oxygen species. Redox Biol. 2018; 14: 126-130.

34. Whyte CS, Swieringa F, Mastenbroek TG, Lionikiene AS, Lancé MD, van der Meijden PE, Heemskerk JW, Mutch NJ. Plasminogen associates with phosphatidylserine-exposing platelets and contributes to thrombus lysis under flow. Blood. 2015; 125(16): 2568-2578.

35. Rand ML, Wang $\mathrm{H}$, Bang KW, Teitel JM, Blanchette VS, Freedman J, Nurden AT. Phosphatidylserine exposure and other apoptotic-like events in Bernard-Soulier syndrome platelets. Am J Hematol. 2010; 85(8): 584-592. 